\title{
HUBUNGAN STATUS GIZI DAN PEMENUHAN KEBUTUHAN GIZI DENGAN KONDISI LUKA PERINEUM PADA IBU POSTPARTUM DI PUSKESMAS PEJUANG DAN PUSKESMAS PEKAYON
}

\author{
1)Christin Natalia, 1)Lina Ayu Marcelina, 1)Indah Permatasari \\ 1,2,3Program Studi Keperawatan, Fakultas Ilmu Kesehatan ${ }^{1)}$ \\ 1,2,3Universitas Pembangunan Nasional Veteran Jakarta
}

\begin{abstract}
ABSTRAK
Proses penyembuhan luka perineum merupakan proses penggantian dan perbaikan fungsi jaringan yang rusak akibat perlukaan yang terjadi di diafragma urogenitalis dan musculus lefator ani pada saat proses persalinan. Penelitian ini dilakukan untuk menambah pengetahuan ibu mengenai pentingnya gizi dalam mendukung perawatan luka perineum dan meminimalisir terjadinya infeksi. Penelitian ini bertujuan untuk mengetahui hubungan status gizi dan pemenuhan kebutuhan gizi dengan kondisi luka perineum pada ibu postpartum di Puskesmas Pejuang dan Puskesmas Pekayon. Penelitian ini merupakan penelitian deskriptif analitik dengan pendekatan cross-sectional dan dianalisis dengan uji Chi-Square. Populasi dalam penelitian ini adalah ibu postpartum yang memiliki luka perineum di UPTD Puskesmas Pekayon dan UPTD Puskesmas Pejuang, dengan sampel 31 orang. Pengambilan sampel dilakukan dengan teknik accidental sampling. Hasil penelitian didapatkan nilai $p$ value sebesar 0,018 dan 0,001 yang menunjukkan bahwa $\mathrm{H}_{1}$ diterima. Sehingga dapat diambil kesimpulann bahwa adanya hubungan antara status gizi dan pemenuhan kebutuhan gizi dengan kondisi luka perineum pada ibu postpartum di Puskesmas Pejuang dan Puskesmas Pekayon. Peneliti menyarakankan ibu postpartum agar lebih mengetahui pentingnya status gizi normal bagi ibu dan dapat memenuhi kebutuhan gizi terutama kebutuhan akan protein untuk mempercepat penyembuhan luka perineum dan meminimalisir terjadinya infeksi.
\end{abstract}

Kata kunci : Status Gizi, Pemenuhan Kebutuhan Gizi, Penyembuhan Luka perineum

\section{ABSTRACT}

The perineal wound healing process is a process of replacing and repairing the function of damaged tissue due to injuries that occur in the urogenital diaphragm and levator ani muscle during childbirth. This study was conducted to increase maternal knowledge about the importance of nutrition in supporting perineal wound care and minimizing the occurrence of infection. This study aims to determine the relationship between nutritional status and fulfillment of nutritional needs with the condition of perineal wounds in postpartum mothers in Pejuang Public Health Center And Pekayon Public Health Center. This study is a descriptive-analytic study with a cross-sectional approach and analyzed by the Chi-Square test. The population in this study were postpartum mothers who had perineal injuries at Pejuang Public Health Center And Pekayon Public Health Center, with a sample of 31 people. The sampling was done by accidental sampling technique. The results of the study obtained p-value values of 0.018 and 0.001 which indicated that $H_{1}$ was accepted. So it can be concluded that there is a relationship between nutritional status and fulfillment of nutritional needs with perineal wound conditions in postpartum women at Pejuang Health Center and Pekayon Health Center. Researchers suggest postpartum mothers know more about the importance of normal nutritional status for mothers and be able to meet nutritional needs, especially for protein to accelerate perineal wound healing and minimize infection.

\section{Keywords: Nutritional Status, Fulfillment of Nutritional Needs, Perineal Wound Healing}

Alamat korespondensi : Fakultas Ilmu Kesehatan, Universitas Pembangunan Nasional Veteran Jakarta, Jalan Limo Raya Kelurahan Limo Kecamatan Limo Kota Depok Kode Pos 16515

Email: lina.ayu@upnvj.ac.id 


\section{PENDAHULUAN}

Morbiditas dan mortalitas pada ibu hamil ataupun ibu bersalin merupakan masalah besar khususnya bagi negara Indonesia. Jumlah Angka Kematian Ibu (AKI) sangat tinggi didunia, menurut World Health Organization (WHO), angka kematian ibu pada tahun 2017 di dunia mencapai 211 per 100.000 kelahiran hidup. Dari hasil survey selama periode tahun 1991-2015 AKI di Indonesia sebesar 305 per 100.000 kelahiran hidup (Kemenkes RI, 2019). Berdasarkan hasil survey, angka kematian ibu pada tahun 2019 di provinsi Jawa Barat sebanyak 74,19 per 100.000 kelahiran ibu atau 684 kasus, dan di Kabupaten Bekasi sebanyak 22 kasus (Dinkes Jabar, 2019). Hasil dari survey tersebut menunjukkan bahwa AKI baik di Indonesia maupun di dunia masih sangat tinggi, kematian ibu dapat terjadi disetiap fase, baik pada masa kehamilan, persalinan maupun pada masa nifas.

Proses persalinan merupakan proses yang lazim terjadi pada seorang ibu. Proses persalinan juga rentan menimbulkan komplikasi dan termasuk salah satu penyebab kematian ibu. Komplikasi yang dapat terjadi pada pasca persalinan salah satunya adalah perdarahan. Berdasarkan hasil survey perdarahan postpartum yang paling banyak menyebabkan kematian ibu secara langsung yaitu sebesar 30,3\%, selain itu yang dapat menyebabkan kematian ibu adalah hipertensi postpartum 27,1\%, infeksi pasca melahirkan 7,3 \%, dan penyebab lain-lain 35,3\% (Satriyandari \& Hariyati, 2017). Infeksi pasca melahirkan merupakan urutan kedua penyebab kematian ibu setelah perdarahan. Infeksi pasca melahirkan dapat terjadi salah satunya dikarenakan oleh adanya laserasi pada perineum, dimana luka pada perineum merupakan daerah yang sulit kering (Lestari, 2016). Angka kejadian infeksi di Indonesia pada ibu yang mengalami robekan perineum pada tahun 2012 sebesar $52 \%$. Sementara itu pada tahun 2012 di provinsi Jawa Barat angka kejadian infeksi perineum sebesar $68 \%$ dari jumlah persalinan normal (Tridiyawati, 2019).

Luka pada perineum dapat terjadi disebagian besar persalinan normal. Luka yang terjadi dapat diakibatkan oleh adanya robekan spontan pada saat proses persalinan maupun robekan yang disengaja atau yang disebut dengan episiotomi. Berdasarkan data SDKI pada tahun 2016, terdapat $57 \%$ ibu yang mengalami luka perineum pada saat persalinan, 28\% diantaranya mengalami luka perineum akibat episiotomi dan 29\% karena robekan spontan (Hasnidar, 2019)

Salah satu dampak dari luka perineum apabila tidak ditangani dengan tepat dapat mengakibatkan terjadinya infeksi perineum. Selanjutnya infeksi perineum tersebut dapat menyebar ke jalan lahir maupun ke saluran kandung kemih yang kemudian dapat mengakibatkan infeksi pada jalan lahir atau infeksi kandung kemih (Manuntungi et al., 2019). Infeksi perineum umumnya disebabkan oleh kurang terjaganya kebersihan perineum. Faktor lain yang dapat menyebabkan infeksi adalah hygiene yang kurang baik, kurangnya daya tahan tubuh ibu, kurang gizi atau mal nutrisi, dan anemia (Kusumawati \& Daramita, 2013).

Penyembuhan luka perineum dapat dipengaruhi oleh beberapa faktor. Salah satu faktor yang mempengaruhi penyembuhan luka adalah faktor gizi. Status gizi merupakan salah satu faktor yang dapat mempengaruhi kesehatan seseorang. Jika ibu nifas mengonsumsi makanan yang bergizi maka kesehatan ibu akan terjaga serta dapat mempercepat penyembuhan luka perineum. Luka dapat dikatakan telah sembuh apabila kontinuitas lapisan kulit telah terjadi. Jika tubuh kekurangan gizi, sel juga akan kekurangan gizi dan proses kontinuitas lapisan kulit akan terhambat sehingga penyembuhan luka akan menjadi lebih lama (Ariani et al., 2020).

Berdasarkan data Riskesdas pada tahun 2018 prevalensi Kurang Energi Kronis (KEK) di provinsi Jawa Barat pada wanita hamil sebesar 14,08\% dan pada wanita tidak hamil sebesar 12,49\%. Sementara itu prevalensi KEK di Kota bekasi pada wanita hamil sebesar 2,20\% dan pada wanita tidak hamil sebesar 15,46\% (Kementerian Kesehatan RI, 2019). Berdasarkan hasil studi pendahuluan yang telah dilakukan oleh peneliti, ditemukan terdapat 3 dari 10 ibu yang mengatakan luka tidak kunjung sembuh hingga 2 minggu pasca melahirkan, dan ketika peneliti kaji lebih lanjut ditemukan 4 dari 10 ibu tersebut status gizinya tidak normal.

Berdasarkan uraian latar belakang diatas yaitu tingginya kejadian luka perineum yang terjadi pada sebagian besar persalinan spontan dan ibu yang memiliki luka perineum tersebut sangat 
berisiko terhadap infeksi terutama apabila ibu tidak dapat melakukan perawatan luka yang baik sehingga luka dapat menjadi pintu masukknya kuman yang akan menyebabkan terjadinya infeksi. Mengingat urgensi tersebut maka peneliti ingin mengetahui lebih lanjut melalui penelitian mengenai adakah hubungan antara status gizi dan pemenuhan kebutuhan gizi ibu dengan kondisi luka perineum.

\section{METODE PENELITIAN}

Penelitian ini merupakan penelitian deskriptif analitik dengan pendekatan cross-sectional dan dianalisa dengan uji Chi-Square. Penelitian ini dilakukan untuk mengetahui Hubungan Status Gizi dan Pemenuhan Kebutuhan Gizi dengan Kondisi Luka Perineum di Puskesmas Pejuang dan Puskesmas Pekayon. Populasi dalam penelitian ini adalah ibu postpartum yang memiliki luka perineum di UPTD Puskesmas Pekayon dan UPTD Puskesmas Pejuang, dengan jumlah sampel 31 orang. Pengambilan sampel dilakukan dengan teknik accidental sampling dengan kriteria inklusi ibu postpartum yang memiliki luka perineum baik episiotomi maupun robekan spontan, melahirkan spontan, ibu postpartum hari ke 7 sampai hari ke 10, bersedia menjadi responden dan dapat memahami bahasa Indonesia. Kriteria eksklusi subyek menolak berpartisipasi, ibu postpartum yang melahirkan secara Caesar, memliki riwayat penyakit yang dapat menghambat proses penyembuhan luka misalnya diabetes melitus. Penelitian ini dilaksanakan pada tanggal 19 April hingga 3 Juni 2021, sedangkan proses pengolahan data dilakukan pada bulan Juni 2021. Instrumen yang digunakan dalam pengambilan data berupa kuesioner dan lembar observasi skala REEDA. Analisa data yang digunakan adalah analisa univariat dan analisa bivariat. Data analisa univariat terdiri dari usia, pendidikan, paritas, status gizi, pemenuhan kebutuhan gizi, dan kondisi luka perineum. Data analisa bivariat terdiri dari status gizi, pemenuhan kebutuhan gizi, dan kondisi luka perineum.

\section{HASIL DAN PEMBAHASAN}

Pada tabel 1 dapat diketahui yakni dari 31 responden rerata ibu berusia 29,65 tahun, artinya rerata usia ibu postpartum pada penelitian ini adalah 30 tahun dengan standar deviasi 6,162. Usia termuda adalah 19 tahun, sedangkan usia tertua adalah 43 tahun.

Tabel 1 Distribusi Rata-rata Responden Berdasarkan Usia Ibu Postpartum di Puskesmas Pejuang dan Puskesmas Pekayon Tahun 2021 (n=31)

\begin{tabular}{llcccc}
\hline \multicolumn{1}{c}{ Variabel } & N & Mean & SD & Min & Max \\
\hline Usia & 31 & 29,65 & 6,162 & 19 & 43 \\
\hline
\end{tabular}


Tabel 2 Distribusi Frekuensi Responden Berdasarkan Karakteristik, Status Gizi, Pemenuhan Kebutuhan Gizi dan Kondisi Luka Perineum Ibu Postpartum di Puskesmas Pejuang dan Puskesmas Pekayon Tahun $2021(n=31)$

\begin{tabular}{lcc}
\hline \multicolumn{1}{c}{ Variabel } & Frekuensi & Presentase (\%) \\
\hline Pendidikan & & \\
$\begin{array}{l}\text { 1. Pendidikan Rendah } \\
\text { 2. Pendidikan Tinggi }\end{array}$ & 12 & 38,7 \\
\hline Paritas & 5 & 61,3 \\
$\begin{array}{l}\text { 1. Primipara } \\
\text { 2. Multipara }\end{array}$ & 25 & 16,1 \\
3. Grand Multipara & 1 & 80,6 \\
\hline Status Gizi & & 3,2 \\
$\begin{array}{l}\text { 1. Tidak Normal } \\
\text { 2. Normal }\end{array}$ & 15 & 48,4 \\
\hline Pemenuhan Kebutuhan Gizi & 16 & 51,6 \\
$\begin{array}{l}\text { 1. Tidak Terpenuhi } \\
\text { 2. Terpenuhi }\end{array}$ & 14 & 45,2 \\
\hline Kondisi Luka Perineum & 17 & 54,8 \\
1. Kurang Baik & & \\
2. Baik & 12 & 38,7 \\
\hline & 19 & 61,3 \\
\hline
\end{tabular}

Berdasarkan tabel 2 dapat dilihat bahwa dari 31 responden mayoritas responden memiliki tingkat pendidikan tinggi (SMA, D3, S1, S2) yaitu sebanyak 20 orang atau 58,8\%, dan sebagiannya lagi memiliki tingkat pendidikan rendah (SD, SMP) yaitu sebanyak 12 orang atau $38,7 \%$. Kemudian dari 31 responden, sebanyak 5 orang atau 16,1\% memiliki riwayat paritas satu kali (primipara) dan 25 orang atau $80,6 \%$ memiliki riwayat paritas dua kali atau lebih (multipara), kemudian sisanya memiliki riwayat paritas $5 \mathrm{kali}$ (grand multipara). Selain itu, pada tabel tersebut juga dapat kita lihat dari 31 responden, sebanyak 15 orang atau 48,4\% masuk kedalam kelompok status gizi yang tidak normal dan 16 orang atau 51,6\% masuk kedalam kelompok status gizi normal. Dengan demikian dapat disimpulkan sebagian besar responden pada penelitian ini masuk kedalam kelompok status gizi normal yaitu 16 responden atau 51,6\%. Selanjutnya untuk kategori pemenuhan kebutuhan gizi didapatkan dari 31 responden, terdapat 14 orang atau 45,2\% masuk kedalam kategori pemenuhan kebutuhan gizi tidak terpenuhi, dan 17 orang atau 54,8\% masuk kedalam kategori pemenuhan kebutuhan gizi terpenuhi. Kemudian terdapat 12 orang atau 38,7\% mengalami kondisi luka yang kurang baik, dan 19 orang lainnya atau 61,3\% mengalami penyembuhan luka yang baik.

Tabel 3 Hubungan Status Gizi dengan Kondisi Luka Perineum Pada Ibu Postpartum di Puskesmas Pejuang dan Puskesmas Pekayon Tahun 2021 (n=31)

\begin{tabular}{|c|c|c|c|c|c|c|c|c|}
\hline \multirow{3}{*}{ Status Gizi } & \multicolumn{4}{|c|}{ Kondisi Luka Perineum } & \multirow{2}{*}{\multicolumn{2}{|c|}{ Total }} & \multirow{3}{*}{$\begin{array}{c}\text { OR } \\
(95 \mathrm{CI} \%)\end{array}$} & \multirow{3}{*}{$p$ value } \\
\hline & \multicolumn{2}{|c|}{ Kurang Baik } & \multicolumn{2}{|c|}{ Baik } & & & & \\
\hline & $\mathbf{N}$ & $\%$ & $\mathbf{N}$ & $\%$ & $\mathbf{N}$ & $\%$ & & \\
\hline Tidak Normal & 9 & $29 \%$ & 6 & $19,4 \%$ & 15 & $48,4 \%$ & 6,500 & 0,018 \\
\hline Normal & 3 & $9,7 \%$ & 13 & $41,9 \%$ & 16 & $51,6 \%$ & & \\
\hline Total & 12 & $38,7 \%$ & 19 & $61,3 \%$ & 31 & $100 \%$ & & \\
\hline
\end{tabular}

Setelah dilakukan Uji analisis menggunakan uji Chi-square didapatkan nilai $\mathrm{p}$ value sebesar 0,018 ( $\mathrm{p}$ value $<0,05$ ) yang artinya bahwa H1 gagal ditolak atau diterima dan $\mathrm{H} 0$ ditolak, sehingga 
dapat diambil kesimpulan bahwa terdapat hubungan yang signifikan antara status gizi dengan kondisi luka perineum pada ibu postpartum di Puskesmas Pejuang dan Puskesmas Pekayon. Tabel 4 Hubungan Pemenuhan Kebutuhan Gizi dengan Kondisi Luka Perineum Pada Ibu
Postpartum di Puskesmas Pejuang dan Puskesmas Pekayon Tahun $2021(\mathrm{n}=31)$

\begin{tabular}{|c|c|c|c|c|c|c|c|c|}
\hline \multirow{3}{*}{$\begin{array}{l}\text { Pemenuhan } \\
\text { Kebutuhan Gizi }\end{array}$} & \multicolumn{4}{|c|}{ Kondisi Luka Perineum } & \multirow{2}{*}{\multicolumn{2}{|c|}{ Total }} & \multirow{3}{*}{$\begin{array}{c}\text { OR } \\
(95 \mathrm{CI} \%)\end{array}$} & \multirow{3}{*}{$p$ value } \\
\hline & \multicolumn{2}{|c|}{ Kurang Baik } & \multicolumn{2}{|c|}{ Baik } & & & & \\
\hline & $\mathbf{N}$ & $\%$ & $\mathbf{N}$ & $\%$ & $\mathbf{N}$ & $\%$ & & \\
\hline Tidak Terpenuhi & 10 & $32,3 \%$ & 4 & $12,9 \%$ & 14 & $45,2 \%$ & 18,750 & 0,001 \\
\hline Terpenuhi & 2 & $6,4 \%$ & 15 & $48,4 \%$ & 17 & $54,8 \%$ & & \\
\hline Total & 12 & $38,7 \%$ & 19 & $61,3 \%$ & 31 & $100 \%$ & & \\
\hline
\end{tabular}

Setelah dilakukan Uji analisis menggunakan uji Chi-square didapatkan nilai $\mathrm{p}$ value sebesar 0,001 yang artinya bahwa $\mathrm{H} 1$ gagal ditolak atau diterima dan $\mathrm{H} 0$ ditolak, sehingga dapat diambil kesimpulan bahwa terdapat hubungan antara pemenuhan kebutuhan gizi dengan kondisi luka perineum pada ibu postpartum di Puskesmas Pejuang dan Puskesmas Pekayon.

Karakteristik usia responden pada penelitian ini rerata ibu postpartum berusia 30 tahun, dimana usia tersebut merupakan usia reproduksi optimal. Menurut Rahayu (2016), usia ialah salah satu faktor yang harus diperhatikan karena dapat menimbulkan komplikasi atau kesakitan baik pada ibu ataupun janin. Usia dalam rentang 20-35 tahun merupakan usia reproduksi optimal seorang ibu, sehingga dianggap paling aman bagi seorang ibu untuk mengalami kehamilan dan persalinan.

Pada penelitian ini mayoritas responden memiliki tingkat pendidikan tinggi (SMA, D3, S1, S2) yaitu sebanyak 20 orang, dimana menurut Afrilia \& Sari (2018), semakin tinggi tingkat pendidikan seseorang maka semakin luas pengetahuan yang dimilikinya. Kemudian mayoritas responden pada penelitian ini memiliki riwayat paritas lebih dari 2 kali atau dapat juga disebut multipara, dimana paritas merupakan salah satu faktor penting yang dapat mempengaruhi proses persalinan maupun kehamilan seorang ibu. Menurut Rahayu (2016) ibu primipara akan memiliki resiko lebih tinggi terhadap ibu dan anak dibandingkan ibu dengan paritas kedua atau ketiga. Hal ini serupa dengan penelitian Suryaningsi (2018), yang menyatakan bahwa ibu primipara lebih beresiko mengalami robekan perineum jika dibandingkan dengan ibu multipara.

Dari hasil analisa data didapatkan bahwa dari 31 ibu postpartum terdapat 15 ibu atau 48,4\% yang mengalami status gizi tidak normal, dimana 9 ibu atau 29\% diantaranya mengalami penyembuhan luka perineum yang kurang baik dan 6 ibu lainnya atau 19,4\% mengalami penyembuhan luka perineum yang baik. Kemudian dari 16 ibu postpartum atau 51,6\% yang mengalami status gizi normal terdapat 3 ibu atau 9,7\% yang mengalami penyembuhan luka perineum yang kurang baik dan 13 ibu lainnya atau 41,9\% mengalami penyembuhan luka perineum yang baik.

Status gizi merupakan hasil akhir dari adanya keseimbangan antara asupan gizi dengan kebutuhan tubuh akan zat gizi tersebut (Zuhana et al., 2017). Status gizi yang kurang dapat terjadi ketika tubuh kekurangan zat-zat esensial secara terus menerus. Apabila kebutuhan akan zat gizi tidak terpenuhi untuk proses penyembuhan luka maka hal tersebut dapat meningkatkan resiko terjadinya infeksi dan akan menyebabkan penyembuhan yang lebih lama (Siswandi et al., 2020). Menurut Maesaroh (2019), semakin baik status gizi seseorang maka penyembuhan luka perineumnya pun akan semakin normal atau cepat, sebaliknya semakin kurang baik status gizi seseorang maka penyembuhan lukanya akan semakin kurang baik atau semakin lama. Hal tersebut disebabkan karena proses penyembuhan luka membutuhkan gizi yang cukup untuk meregenerasi jaringan tubuh yang rusak terutama protein, sehingga status gizi yang baik menunjukkan bahwa ketersediaan akan protein didalam tubuh juga baik dan sebagian akan digunakan untuk penyembuhan luka. 
Dengan demikian ibu postpartum yang memiliki status gizi yang baik cenderung akan mengalami penyembuhan luka perineum yang baik juga.

Menurut Boyle (2008), penyembuhan luka merupakan proses penggantian dan perbaikan fungsi jaringan yang rusak. Tahapan penyembuhan luka terdiri atas fase inflamasi, fase proliferasi, dan fase maturasi. Fase inflamasi terjadi dari awal cedera sampai 5 hari setelah cedera terjadi. Pada fase inflamasi terdapat beberapa proses fisiologis yang terjadi seperti terdapat kemerahan, edema, nyeri pdisekitar daerah luka. Kemudian fase proliferasi berlangsung sampai 21 hari dimana pada tahapan ini luka dipenuhi jaringan granulasi dan terdapat epitelisasi di pinggir luka. Selanjutnya fase terakhir penyembuhan luka yaitu maturasi, dimana pada tahapan ini epitelisasi menutupi seluruh permukaan luka (Wijaya, 2018). Pada penelitian ini proses penyembuhan luka perineum berada di fase proliferasi, dimana penyembuhan luka dapat dikatakan baik atau sesuai dengan fase penyembuhan luka apabila pada responden tidak ditemukan lagi tanda-tanda inflamasi seperti kemerahan dan lain-lain.

Kemudian berdasarkan analisa data, ditemukan bahwa dari 31 ibu postpartum terdapat $14 \mathrm{ibu}$ atau $45,2 \%$ yang kebutuhan gizinya tidak terpenuhi, dimana $10 \mathrm{ibu}$ atau 32,3\% diantaranya mengalami penyembuhan luka perineum yang kurang baik dan 4 ibu lainnya atau 12,9\% mengalami penyembuhan luka perineum yang baik. Kemudian dari $17 \mathrm{ibu}$ postpartum atau 54,8\% yang mengalami pemenuhan kebutuhan gizi terpenuhi terdapat 2 ibu atau 6,4\% yang mengalami penyembuhan luka perineum yang kurang baik dan 15 ibu lainnya atau 48,4\% mengalami penyembuhan luka perineum yang baik. Berdasarkan hasil pengisian angket menunjukkan bahwa mayoritas responden rutin mengonsumsi makanan pokok yang mengandung karbohidrat seperti nasi sebanyak 3x dalam sehari atau sebanyak 300 sampai 500 gram per hari. Selain itu responden juga mengonsumsi makanan yang tinggi akan protein, baik itu protein nabati seperti tahu dan tempe sebanyak 4-6 potong atau sebanyak 100-150 gram per hari, maupun protein hewani seperti ikan, telur, ayam atau daging sebanyak 2 potong atau 100 gram perhari. Kemudian responden juga mengonsumsi sayur- sayuran sebanyak 150-200 gram per hari dan buah-buahan sebanyak 2 potong per hari.

Pada penelitian ini terdapat juga responden yang pemenuhan kebutuhan gizinya tidak terpenuhi dan mengalami penyembuhan luka perineum kurang baik yang berjumlah $10 \mathrm{ibu}$ atau $29,4 \%$. Hal ini disebabkan karena zat gizi yang dibutuhkan untuk proses penggantian dan perbaikan fungsi jaringan yang rusak tidak cukup sehingga proses penyembuhan luka perineum menjadi kurang baik. Menurut Hardianty et al. (2020), zat gizi khususnya protein berperan penting dalam proses penyembuhan luka karena penggantian dan perbaikan fungsi jaringan sangat membutuhkan protein. Pada proses penyembuhan luka perineum kebutuhan akan protein akan meningkat yang berguna untuk proses inflamasi dan perkembangan jaringan granulasi. Protein akan mensuplai asam amino yang diperlukan untuk perbaikan jaringan dan regenerasi, sehingga tubuh harus memiliki ketersediaan protein sebanyak 100 gram per hari untuk dapat menetralisir penyembuhan luka dengan baik (Sari \& Fajri, 2020). Sehingga jika pemenuhan kebutuhan gizi ibu tidak terpenuhi terutama kebutuhan akan protein maka penyembuhan luka akan lama atau kurang baik, sebaliknya jika pemenuhan kebutuhan gizi ibu terpenuhi, asupan makanan sesuai dengan diet maka akan mempercepat penyembuhan luka perineumnya, luka perineumnya akan menutup dan disertai jaringan parut.

\section{SIMPULAN}

Berdasarkan hasil analisa dan penelitian mengenai hubungan status gizi dan pemenuhan kebutuhan gizi dengan kondisi luka perineum pada ibu postpartum menggunakan uji Chi-Square dan didapatkan hasil $p$ value sebesar 0,018 ( $p$ value $<0,05$ ) yang menunjukkan arti Ha diterima maka terdapat hubungan yang signifikan antara status gizi dengan kondisi luka perineum pada ibu postpartum di Puskesmas Pejuang dan Puskesmas Pekayon, kemudian terdapat hubungan yang signifikan antara pemenuhan kebutuhan gizi dengan kondisi luka perineum pada ibu postpartum di Puskesmas Pejuang dan Puskesmas Pekayon dengan $p$ value sebesar 0,001 ( $\mathrm{p}$ value $<0,05$ ). 


\section{SARAN}

Berlandaskan hasil penelitian, peneliti mengharapkan masyarakat khususnya ibu postpartum dapat mengetahui pentingnya status gizi normal bagi ibu serta ibu juga dapat memenuhi kebutuhan gizinya terutama kebutuhan akan protein untuk mempercepat penyembuhan luka perineum dan meminimalisir terjadinya infeksi. Peneliti menyarankan baiknya tenaga kesehatan mampu mengedukasi atau memberikan penyuluhan kepada ibu postpartum akan pentingnya status gizi yang normal dan memenuhi kebutuhan gizi terutama protein selama masa nifas untuk mendukung pemulihan masa nifas khususnya penyembuhan luka perineum. Lalu peneliti juga menyarankan untuk penelitian selanjutnya yang akan membahas terkait topik yang sejenis agar menjadikan penelitian ini sebagai acuan dalam melakukan penelitian, dan diharapkan pada penelitian selanjutnya dapat dilakukan dengan subjek yang lebih banyak serta hendaknya dapat menambah faktor lain yang mempengaruhi penyembuhan luka perineum selain faktor yang telah digunakan. Selain itu, untuk penelitian selanjutnya juga dapat dilakukan dengan metode yang berbeda seperti quasi eksperimen untuk mempercepat penyembuhan luka perineum.

\section{DAFTAR PUSTAKA}

Afrilia, E. M., \& Sari, H. (2018). Hubungan Pengetahuan Ibu Nifas Tentang Perawatan Luka Perineum Dengan Proses Penyembuhan Luka Ruptur Perineum Di Puskesmas Pakuhaji Kabupaten Tangerang. Indonesian Midwiwery Journal, http://jurnal.umt.ac.id/index.php/imj/article/viewFile/980/1347

Ariani, P., Fahmila, Y., Ariescha, P. ayu yessy, Yanti, M. D., \& Siagian, N. aini. (2020). Hubungan Status Gizi Dengan Lama Penyembuhan Luka Post Sectio Cesarea. Journal of Chemical Information and Modeling, 53(9), 1689-1699.

Boyle, M. (2008). Pemulihan Luka : Seri Praktik Kebidanan. EGC.

Dinkes Jabar. (2019). Profil Kesehatan Jawa Barat Tahun 2019. Journal of Chemical Information and Modeling, 53(9), 1689-1699.

Hardianty, D., Kartika, D., \& Mualimah, M. (2020). Hubungan Antara Pantang Makanan Ibu Nifas Dengan Kecepatan Penyembuhan Luka Perineum Di Puskesmas Nosarara Kota Palu Tahun 2020. Jurnal Kesehatan Mahasiswa Universitas Kadiri, 2(2), 36-45. http://ojs.unikkediri.ac.id/index.php/jumakes/article/view/1171/pdf

Hasnidar. (2019). Luka Jahitan Perineum Pada Ibu Nifas Di Uptd Puskesmas Watampone Tahun 2018. 14, 122-127.

Hastuti, P., \& Wijayanti, I. T. (2017). Analisis Deskriptif Faktor yang Mempengaruhi Pengeluaran ASI pada Ibu Nifas di Desa Sumber Kecamatan Sumber Kabupaten Rembang. Jurnal Universitas Muhammadiyah Magelang, 6,

223-232. http://journal.ummgl.ac.id/index.php/urecol/article/view/1028

Kemenkes RI. (2019). Profil Kesehatan Indonesia 2018 [Indonesia Health Profile 2018]. http://www.depkes.go.id/resources/download/pusdatin/profil-kesehatan-indonesia/Datadan-Informasi_Profil-Kesehatan-Indonesia-2018.pdf

Kementerian Kesehatan RI. (2019). Laporan Provinsi Jawa Barat, Riskesdas 2018. In Lembaga Penerbit Badan Penelitian dan Pengembangan Kesehatan.

Kusumawati, E., \& Daramita, N. (2013). Hubungan Pola Nutrisi Sosial Ekonomi ,Personal Higiene Dengan Kejadian Infeksi Pada Luka Perineum.

Lestari, P. (2016). Usia Berpengaruh Dominan Terhadap Perilaku Perawatan Luka Perineum pada Ibu Nifas di RSUD Sleman. Jurnal Ners Dan Kebidanan Indonesia, 4(2), 95. https://doi.org/10.21927/jnki.2016.4(2).95-101

Maesaroh. (2019). Pengaruh Status Gizi Ibu Nifas Terhadap Penyembuhan Luka Post Partum Operasi Sectio Caesarea. Jurnal Kesehatan Pertiwi, 1(Politeknik Kesehatan Bhakti Pertiwi), 1.

Manuntungi, A. E., Irmayanti, \& Ratna. (2019). Faktor-Faktor yang Mempengaruhi Lamanya Penyembuhan Luka Perineum pada Ibu Nifas di Ruang Perawatan Rumah Sakit Mitra Manakarra Mamuju. Nursing Inside Community, 1(3), 96-103. 
https:// doi.org/10.35892/nic.v1i3.231

Rahayu, P. P. (2016). Faktor Yang Berhubungan Dengan Kejadian Ruptur Perineum Di Puskesmas Mergangsan Kota Yogyakarta Tahun 2014. Issn : 1907 - 3887, XI(April), 22-30.

Sari, D. N., \& Fajri, U. N. (2020). Hubungan Antara Umur, Nutrisi Dan Indeks Masa Tubuh Terhadap Penyembuhan Luka Post SC Pada Ibu Nifas. 39(10), 4444-4455.

Satriyandari, Y., \& Hariyati, N. R. (2017). Faktor-Faktor Yang Mempengaruhi Kejadian Perdarahan Postpartum. Journal of Health Studies, 1(2), 49-64. https:/ / doi.org/10.31101/jhes.185

Siswandi, A., Wulandari, M., Erianto, M., \& Mawaddah, A. (2020). Hubungan Status Gizi dengan Proses Penyembuhan Luka pada Pasien Post Apendektomi. ARTERI : Jurnal Ilmu Kesehatan, 1(3), 226-232. https://doi.org/10.37148/arteri.v1i3.66

Suryaningsi, A. (2018). Hubungan Paritas Dan Berat Badan Lahir Bayi Dengan Kejadian Ruptur Perineum Spontan Di Puskesmas Jetis Yogyakarta. 1-12.

Tridiyawati, F. (2019). Kontribusi Pengetahuan Ibu Nifas Terhadap Perawatan Luka Perineum. 2(2), 54-62.

Wijaya, I. M. S. (2018). Perawatan Luka Dengan Pendekatan Multidisiplin (R. I. Utami (ed.)). Andi. https:/ / books.google.co.id/books?id=pVJtDwAAQBAJ\&printsec=frontcover\&dq=perawatan +luka+dengan+pendekatan+multidisiplin\&hl=jv\&sa=X\&redir_esc $=y \# v=$ onepage\&q=perawat an luka dengan pendekatan multidisiplin\& $\mathrm{f}=\mathrm{false}$

Zuhana, N., Prafitri, L. D., \& Ersila, W. (2017). Indeks Masa Tubuh terhadap Penyembuhan Luka Perineum Ibu Nifas. Jurnal Ilmiah Kesehatan, 10(2). https:/ / doi.org/10.48144/jiks.v10i2.78 